Article

\title{
Application of an innovative effluent capture and evacuation device that increases the efficiency of subsurface flow wetlands
}

\author{
Pedro Cisterna-Osorio*; Gisela Silva-Vasquez; Mauricio Llanos-Baeza, Verónica Lazcano-Castro and \\ Ignacio Fuentes-Ortega
}

Department of Civil and Environmental Engineering, Universidad del Bío Bío.

* Correspondence: pcisterna@ubiobio.cl; Tel.: +56-41-3111658

\begin{abstract}
The objective of this work is to evaluate the impact of the innovative modifications made to the conventional effluent capture and discharge devices used in subsurface flow wetlands (SSFW). The main modifications developed consist on extending the influence of the capture and discharge device in such a way that the SSFW width and height are fully covered. This improved innovative device was applied and evaluated in two subsurface flow wetlands, one on a pilot scale and one on a real scale. To evaluate the impact of the innovative device with respect to conventional one in the operational functioning of subsurface flow wetlands, the elimination of chemical oxygen demand was measured and compared. The results show that for the innovative device, the COD removal was $10 \%$ higher than for the conventional device, confirming the validity and effectiveness of the modifications implemented in the effluent capture and discharge devices used in SSFW.
\end{abstract}

Keywords: Artificial Wetlands; Horizontal Wetland; Subsurface Flow

\section{Introduction.}

The aim of this work is to evaluate the impact on the SSFW behavior by incorporating an innovative device in the capture and exit of the effluents from horizontal subsurface wetlands. Said device was installed in a pilot-scale wetland and in a real-scale wetland. As a consequence, there was an increase in the efficiency of Chemical Oxygen Demand (COD) removal, from domestic wastewater, at a low cost of investment, operation and maintenance, and was complying with the water quality standards required by the current regulations of the country. Artificial wetlands have been validated as an alternative wastewater treatment option to the conventional systems

It is considered that the water is contaminated, when their chemical, physical and biological characteristics or composition has been altered, this is, it loses their potability for daily consumption or for its use in domestic, industrial or agricultural activities, which generates wastewater [1]. This statement applies regardless of domestic, industrial, agricultural, or rainwater origin [2].

Wastewater generated in human activities has a high load of organic material, which is measured through the COD. Additionally, it contains toxic substances and inorganic matter in small quantities and, as a consequence, the sum of both components pollute water sources undermining the sustainability of water provision and consequently, the sustainability of the humanity itself. Therefore, treatment systems including physical, chemical and biological processes have been developed and widely implemented. The objective of such processes is to reduce the load of pollutants from wastewater and, ideally, to recover, recycle and reuse them before pouring it into bodies of surface water [3].

On the other hand, it is pertinent to recover water from these liquid waste, which requires the elimination of substances harmful to health and the environment, which will benefit the population. [4]. Efficient treatment systems have been developed for the removal of pollutants, which are also economically, technically and socially feasible. One example of those treatments is the Artificial Wetlands of SubSuperficial Flow (WSSF), [5]. Other authors have proposed that contaminants removal levels can 
be increased by modifying the design of the input geometry of the wetland or by modifying the form of distribution of the flow and its direction within the system [6].

Artificial wetlands can efficiently reduce the Biochemical Oxygen Demand (BOD), Total Suspended Solids (TSS), achieving adequate treatment levels with low energy consumption and simple and economic maintenance procedures [7]. However, the rate of organic matter biodegradation is lower, requiring typically 20 to 50 times more land area than in conventional systems [8].

In artificial wetlands soluble organic compounds are biodegraded by aerobic processes where oxygen is supplied directly from the atmosphere by diffusion and mainly through the process of photosynthesis, into the water column [9]. Microorganisms that are attached to the support medium in subsurface flow systems are those that biodegrade the soluble organic compounds [10]. The degradation rate is typically 10 times faster than anaerobic processes [11]. On the other hand, aerobic processes are the main mechanism to reduce soluble BOD, and the elimination of particulate BOD occurs rapidly by sedimentation and particle filtration in the spaces between gravel and roots [12].

The structural factors that affect the removal of organic matter are related to the depth of the wetland, which in turn is conditioned by the plant's root depth, depending directly on the species of plant used. The most commonly used plant species are emergent macrophytes typical of humid areas such as reed (Phragmites sp.), Bulrush (Typha sp.) or reeds (Scirpus sp.) [13].

These plants show great adaptation to saturated environments, fast growth, strength and resistance to climatic changes, and also they do not constitute a source of food for animals [14]. One criterion for plants selection is the adaptability to the environmental conditions where a wetland is planned to be built, for this reason, local flora species are preferred [13].

Hence, in wetlands feeding is continuous and the water cross horizontally a filtering substrate composed by gravel, following its course by the effect of gravity, given the smooth slope on the bottom towards the exit of the wetland. This arrangement allows the contact between the residual water, the substrate and the plant's roots with the hydraulic retention time ranging from 2 to 5 days. An impermeable barrier is considered in order to confine the residual water and avoid groundwater contamination. This barrier is required to be resistant, smooth and protected against puncturing by sharp gravel [15]. The most used waterproofing material is high-density polyethylene. Regarding the filtering substrate, it is recommended to use gravel of ASTM 11/4" to ASTM 3/4", the diameter effect over the system can be summarized as follows: larger diameters increase water speed, whereas small diameter, reduce the speed causing possible floods and preferential flows [16].

The ratio (length: width) must be greater than (3:1) to approximate a piston-type flow, which is directly related to the slope used at the bottom of the wetland bed, which determines the flow speed [17]. The most common range for the slope goes from 0.5 to $1 \%$. [18].

In terms of modeling the system dynamics, the Basic Model of Organic Matter Removal is applied in piston flow reactors [19]. This model has been validated [20] and relates the contaminants removal capacity and the hydraulic residence time.

$$
\begin{gathered}
\text { Equations: } \\
\frac{d C a}{d t}=K_{T} * C a \ldots \ldots . .1 \\
\frac{C e}{C o}=\exp \left(-K_{T} * H R T\right) \ldots \ldots .2 \\
H R T=\frac{V}{Q}=\frac{A s * h * n}{Q} \ldots \ldots .3 \\
A_{S}=Q * \frac{\ln \frac{C O}{C e}}{K_{T} * y * n} \ldots \ldots . . .4
\end{gathered}
$$


The Table 1 defines the variables and parameters used in the sizing of subsurface flow wetlands.

Table 1 Parameters of design

\begin{tabular}{cc}
\hline Co & Concentration of BOD in influent, $\mathbf{m g} / \mathbf{1}$ \\
\hline Ce & Concentration of BOD in effluent, $\mathrm{mg} / \mathbf{1}$ \\
HRT & Hydraulic residence time, day \\
As & Surface area of the wetland, $\mathrm{m} 2$ \\
$\mathrm{~N}$ & Porosity of the wetland \\
$\mathrm{Y}$ & Depth of water in the wetland, $\mathrm{m}$ \\
$\mathrm{Q}$ & Average flow rate of the wetland, $\mathrm{m} 3 / \mathrm{day}$ \\
$\mathrm{V}$ & Volume of the wetland, $\mathrm{m} 3$ \\
$\mathrm{~K}_{\mathrm{T}},(1 / \mathrm{d})$ & Constant dependent on temperature, $=\mathrm{K}_{20} * 1,06^{\mathrm{T}-20}$ \\
$\mathrm{t}$ & day \\
\hline
\end{tabular}

$\mathrm{K}_{20}=1.104 \mathrm{~d}^{-1}$ Constant kinetics of organic matter removal at $20^{\circ} \mathrm{C}$.

Knowing the above, this work it has its origin in the critical reflection that is made to the structure and conventional configuration of the capture and evacuation device of the effluent, which are located in the middle and bottom points, what generates preferential flows. This work shows an innovative and improved effluent capture and discharge device, patented in 2018, which modifies its structure and configuration, which capture the treated wastewater throughout the width of the wetland and the height of the water column, such that converge to the outlet tube finally.

Given the structure of the conventional device, the capture of the effluent occurs in the bottom (figure $4 a)$, unlike the innovative device that the effluent flows in the entire water column (figure $4 \mathrm{~b}$ ). The innovative device has an effective height higher than that of the conventional device, since it has a greater effective volume, due to the fact that it has a smaller lost volume associated with the generation of preferential flows.

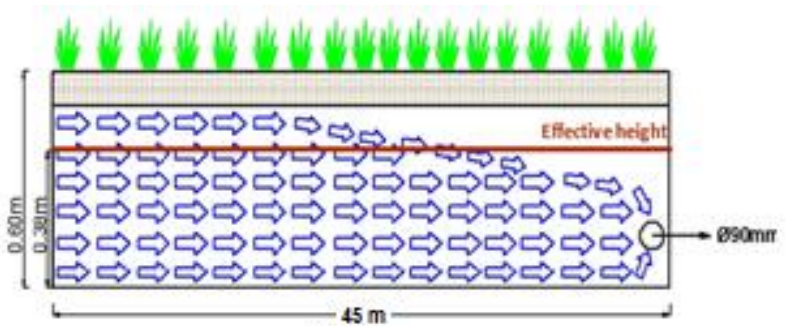

(A)

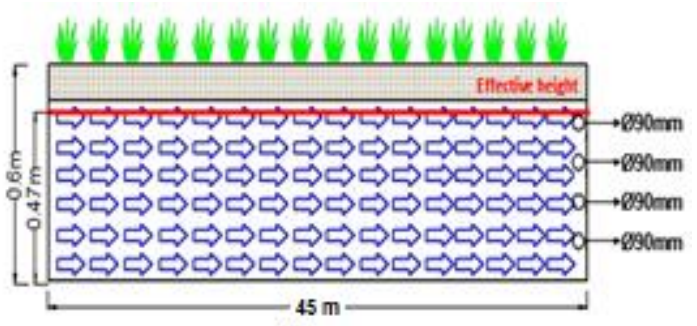

(B)

Figure 4. Effective height with (A) the conventional device and (B) the innovative device.

Something similar happens with the occupation of the wetland area, for the innovative device, the effluent is collected throughout the width of the wetland, which minimizes the area lost (Figure 5).
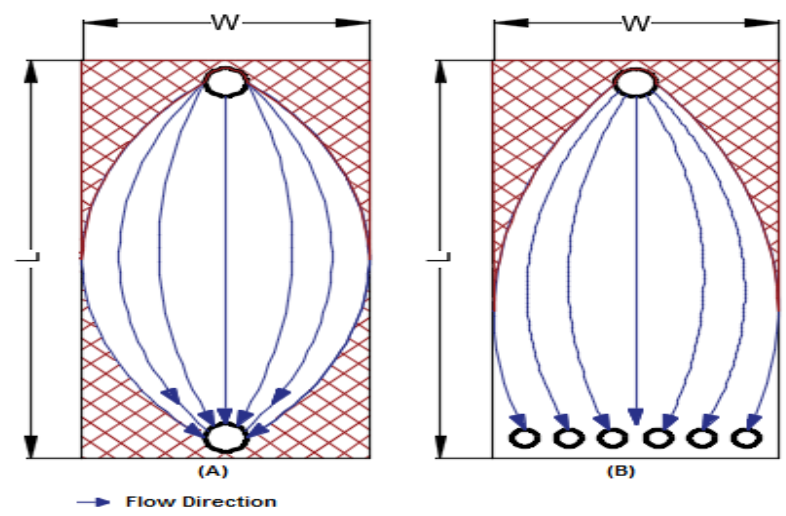

Figure 5. Effective area with (A) the conventional device and (B) the innovative device. 


\section{Materials and Methods}

The capture and exit device was installed in two different wetlands, the first a pilot-scale wetland, located in dependencies of the University of Bío Bío, Campus Concepción, in the city of Concepción, and the other, in the subsurface flow wetland of Recreational Center Ainahue, located in Hualqui, province of Concepción, whose coordinates are U.T.M. 686393.79 m E; 5905081.35 m S (Figure 1), Chile.

Pilot Wetland:

Two horizontal subsurface flow wetlands of dimensions $2.0 \times 0.6 \mathrm{~m}$ (Table 2) were built, one of them using the proposed modifications in the capture and evacuation effluent device and the other using the conventional device. Both were connected to the same pond, which provided the synthetic wastewater.

Real-scale Wetland:

In the constructed wetland of Recreational Center Ainahue, conventional and innovative device were used alternately, to analyze the behavior of the wetland, based on them.

The samples were taken during a period of three weeks approximately, while using the innovative device. Then we proceeded to use the traditional device. During the first seven days of operation of the device no samples were taken, so that the wetland would adapt to the hydrodynamics change. After this pause, sampling was started for the conventional device, which was also during a period of three weeks.

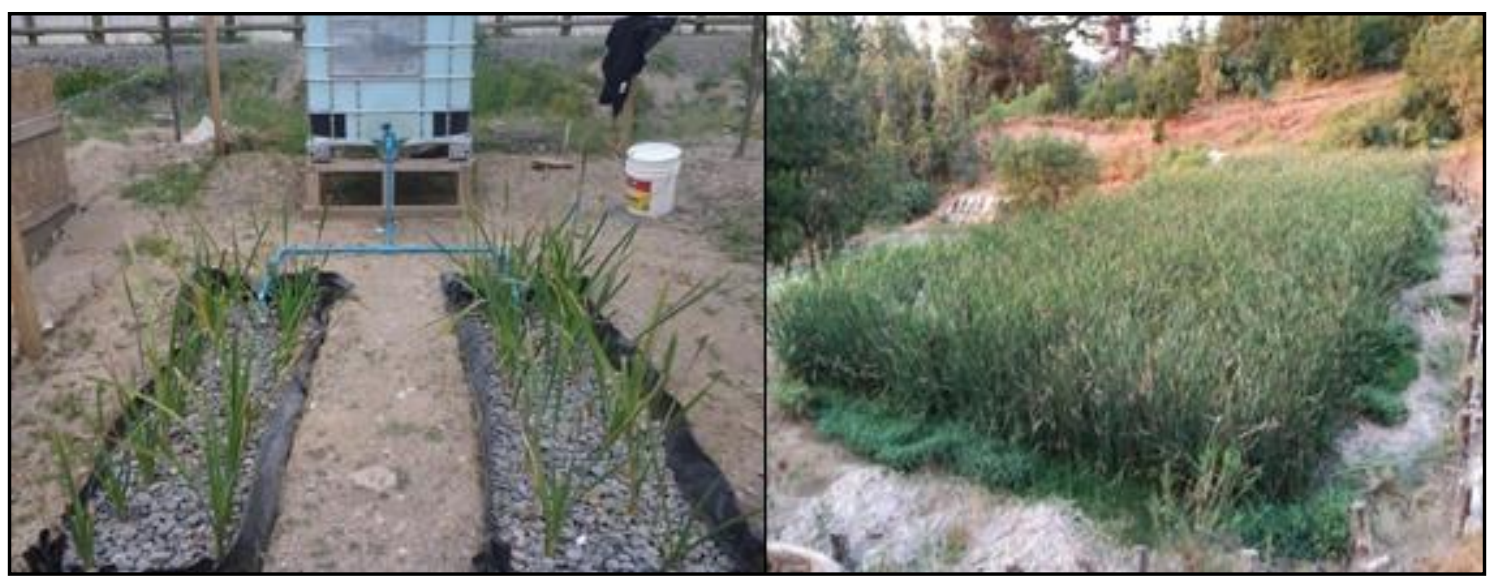

Figure 1. Wetlands of horizontal subsurface flow. (Left) Pilot wetlands, located in dependencies of the University of Bío Bío, Concepción. (Right) Real-scale wetland, located in the Recreational Center Ainahue, Hualqui.

Table 2. Dimensions of Wetland Sub-surface Horizontal Flow.

\begin{tabular}{cccc}
\hline Parameter & Symbol & $\begin{array}{c}\text { Pilot Wetland } \\
\text { Characteristics }\end{array}$ & $\begin{array}{c}\text { Real Wetland } \\
\text { Characteristics }\end{array}$ \\
\hline Flow $\left(\mathrm{m}^{3} /\right.$ day) & $\mathrm{Q}$ & 0,2 & 48 \\
Length $(\mathrm{m})$ & $\mathrm{L}$ & 2 & 45 \\
Width $(\mathrm{m})$ & $\mathrm{W}$ & 0.6 & 13 \\
Length / width ratio & $\mathrm{L} / \mathrm{W}$ & 3.33 & 3.46 \\
Depth $(\mathrm{m})$ & $\mathrm{Y}$ & 0.55 & 0.6 \\
Porosity Dry gravel $(\%)$ & $\mathrm{N}$ & 0.42 & 0.38 \\
Slope (m/m) & $\mathrm{S}$ & 0.002 & 0.005 \\
Surface Area $\left(\mathrm{m}^{2}\right)$ & $\mathrm{As}$ & 1.2 & 585 \\
Transverse Area (m $\left.\mathrm{m}^{2}\right)$ & Ac & 0.033 & 7.8 \\
Hydraulic Residence Time (dia) & HRT & 1,2 & 2,8 \\
Vegetation & & Typha & Typha \\
\hline
\end{tabular}


Physical-Chemical Parameters and Analytical Methods

\section{Chemical Oxygen Demand (COD)}

The potassium dichromate method was used to evaluate COD levels. This method is a variation of the standard method [21], however, it maintains the basis of it. The variation used has the advantage that it requires a smaller sample and reagents. The sample is chemically oxidized through the action of potassium dichromate at $150{ }^{\circ} \mathrm{C}$ for two hours. Silver sulfate is used as a catalyst and mercury sulfate to avoid possible interferences with chloride. Afterwards, determination by spectrophotometry at $600 \mathrm{~nm}$ is performed. Equipment and instruments were used to determine the various parameters to characterize the wastewater.

\section{Determination of Chemical Oxygen Demand (COD)-Substrate Relationships}

Samples composed by mixtures of water and substrates prepared at different concentrations, and their respective COD was estimated. This test is performed in order to produce a calibration curve and establish the ratio substrate concentration/COD.

\section{Experimental Methodology}

\section{Pilot Wetland:}

\section{a. Feed Preparation}

This pilot wetland was initially fed with synthetic wastewater prepared in the laboratory according to the typical characteristics of urban wastewater [22]. This wastewater has an approximate COD of 200$300 \mathrm{mg} / \mathrm{L}$, with the corresponding proportions of nitrogen and phosphorus, in a relation of COD:N:P = 100:5:1. Approximately 200-300 mg of saccharose, 10-15 mg of phosphate hydrogen of potassium, and 50$75 \mathrm{mg}$ of ammonium chloride were added per liter of water.

\section{b. Operation Mode}

The synthetic wastewater was poured into a storage pond of almost $1000 \mathrm{~L}$, Process effluent is collected in a $30 \mathrm{~L}$ volume tank, where the samples are taken to be processed. The flow of synthetic wastewater is $2 \mathrm{~m} 3 /$ day.

\section{Description of conventional and innovative output devices.}

\section{Conventional Exit Device}

The conventional device consists of a PVC pipe $90 \mathrm{~mm}$ in diameter and $13 \mathrm{~m}$ in length with perforations of approximately $10 \mathrm{~mm}$ along its length, for the capture of the effluent (Figure 2). It is located approximately $0.2 \mathrm{~m}$ from the bottom of the wetland. The collection of the effluent water is done with a perforated pipe settled on the bottom of the wetland. Then, it is directed towards the exit by means of a syphon, which allows to maintaining the water level inside the wetland.

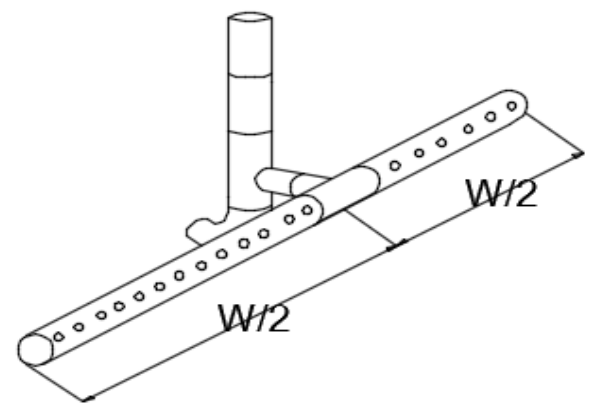

Figure 2. Conventional outlet device for the effluent of the subsurface flow wetland. 
Description of the Innovative device

The innovative exit device of the artificial wetland, consists of 4 sanitary PVC pipes $90 \mathrm{~mm}$ in diameter and $13 \mathrm{~m}$ long, located at different heights, in climbing form at $0.15 \mathrm{~m}$ and $0.2 \mathrm{~m}$ from the bottom of the wetland, with $10 \mathrm{~mm}$ perforations in diameter (Figure 3).

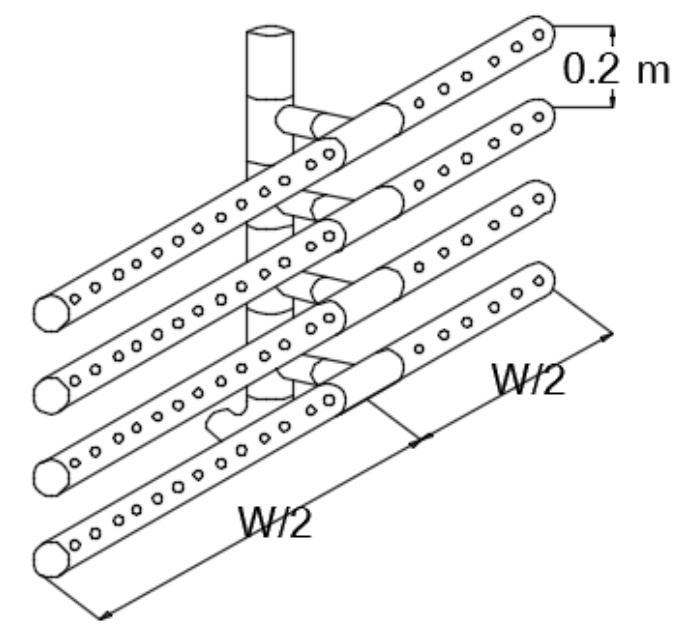

Figure 3. Innovative outlet device for the effluent of the subsurface flow wetland, Patent Registration Number: 503, INAPI, Chile, February 2018 [23].

Sampling and operation of the constructed wetland

Effluents samples from the artificial wetland, as shown in Figure 6, were sent periodically to laboratory analysis to measure the chemical oxygen demand (COD) and total suspended solids (TSS), using the standardized method. In parallel, the flow was estimated.

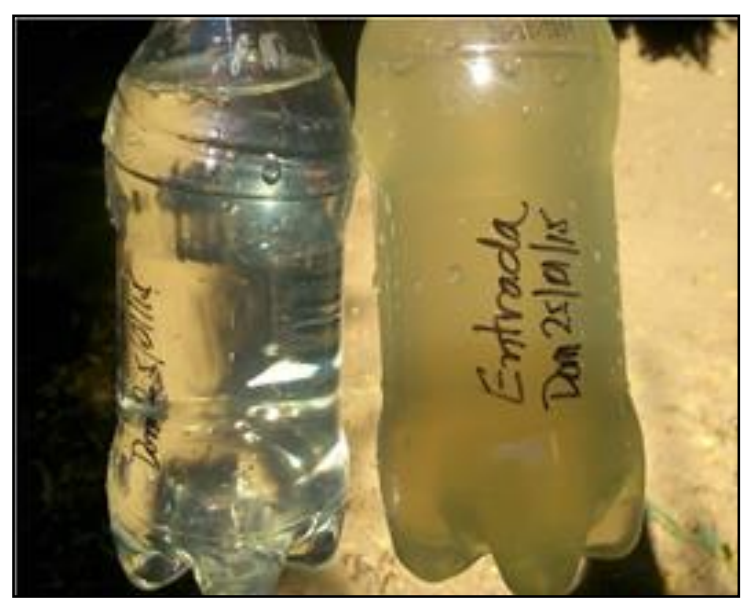

Figure 6. Effluent and affluent sample 


\section{Results and Discussion}

\subsection{COD-Concentration of saccharose Relationships}

From the experimental results, a straight line regression with a slope of 1.17 is obtained, as shown in Figure 7, from which it can be stated that the saccharose has one COD per gram, which is above other organic substances [24]. The model obtained is: $Y=1.17 \mathrm{X}$, where $\mathrm{Y}$ : concentration saccharose and $\mathrm{X}: \mathrm{COD}$ of saccharose.

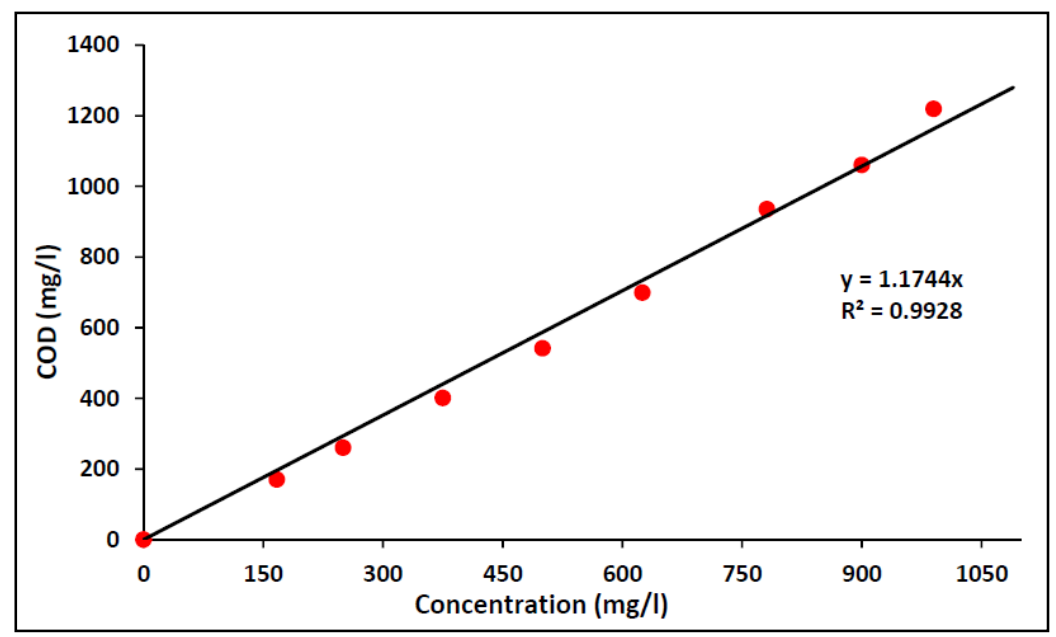

Figure 7. COD-saccharose relationship.

\subsection{COD concentration of the artificial wetland}

Figure 8 and Figure 9 shows the input and output concentrations of COD, using the conventional and innovative effluent capture and evacuation device. Using the COD as an assay, we estimate the abatement efficiency that is reached in the real wetland, obtaining average efficiencies for the innovative and conventional devices of $92 \%$ and $84 \%$ respectively in the full-scale wetland. For the case of pilot wetlands, the efficiencies obtained were $69 \%$ and $63 \%$ respectively. Therefore, a better performance is demonstrated for the use of the innovative device, the percentage increase is $10 \%$ for both cases.

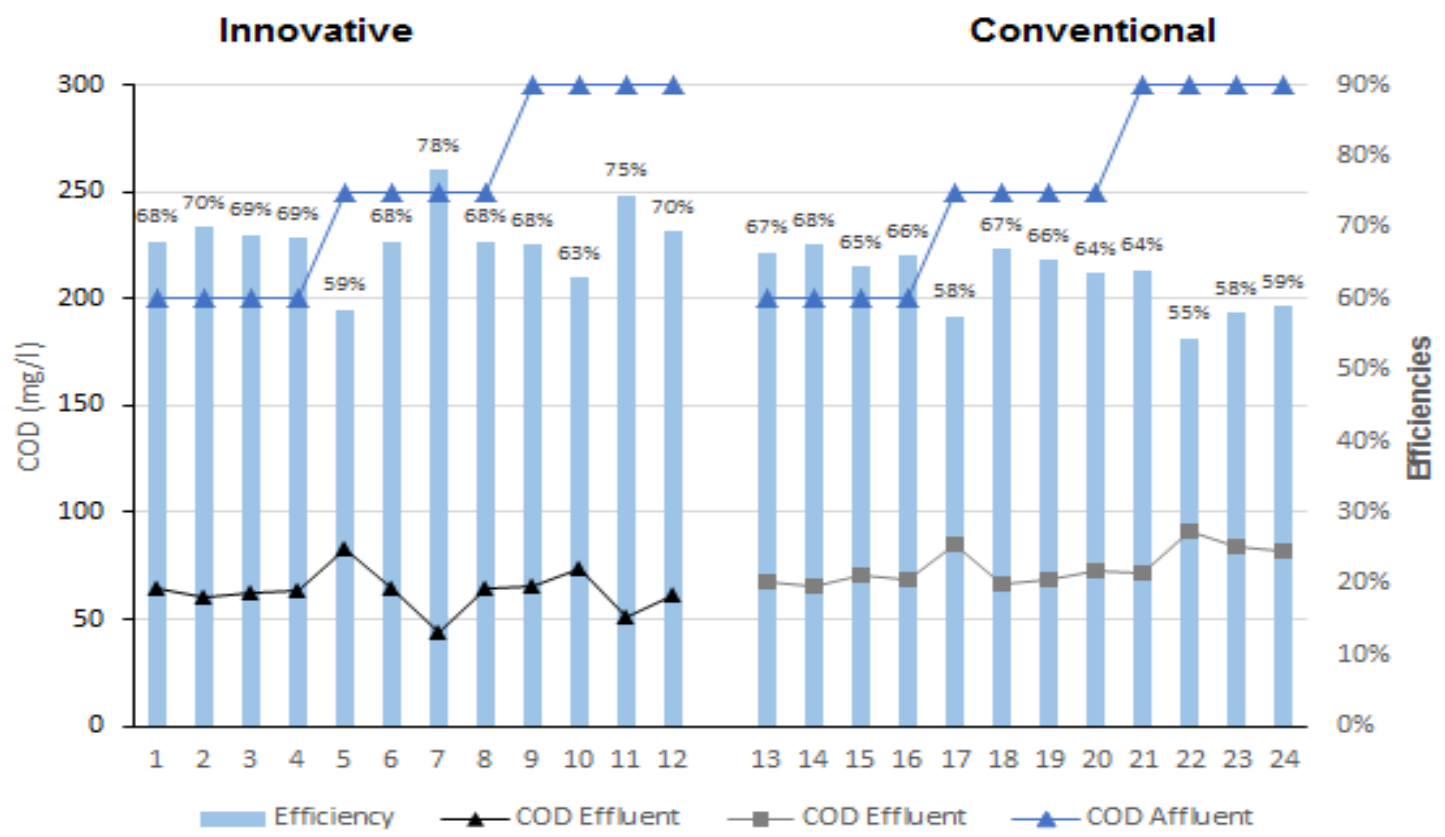

Figure 8. COD concentration in affluent and effluent in a Pilot-scale wetland. 
Works done with similar results to the pilot wetland are the following, Conducted a nine-month campaign for a horizontal subsurface flow wetland, which treats rural wastewater in the Cova Beira region. These concentrations in the influent were $506 \mathrm{mg} / \mathrm{L}$ of BOD and $677 \mathrm{mg} / \mathrm{L}$ of COD, where the average efficiencies were $83 \%$ for BOD and $68 \%$ for COD, respectively. [25]

[26] It studied the application of halophytic plants in a horizontal subsurface flow wetland constructed for the treatment of domestic wastewater. The pilot plant located in Greece was planted with a polycropping of halophytes (Tamarix parviflora, Juncus acutus, Sarcocornia perrenis and Limoniastrum monopetalum). The results show that the halophytes were successfully developed in the constructed wetland, where, the average BOD concentration of $106 \mathrm{mg} / \mathrm{L}$ in the influent; with an average elimination of approximately $63 \%$, it obtained removal efficiency for COD of $58 \%$.

The COD elimination efficiencies of the mentioned experiences are similar to those of the pilot wetlands that have COD elimination efficiencies of $63 \%$ with conventional device and $69 \%$ with innovative device, with the application of the innovative patented device, the efficiencies could be improved respective, the Cova Beira Wetland of 68 to $75 \%$ and the wetland of Greece from 58 to $64 \%$, therefore there is a feasibility to improve the efficiency of COD removal of these systems, which can be achieved by incorporating the innovative patented device.

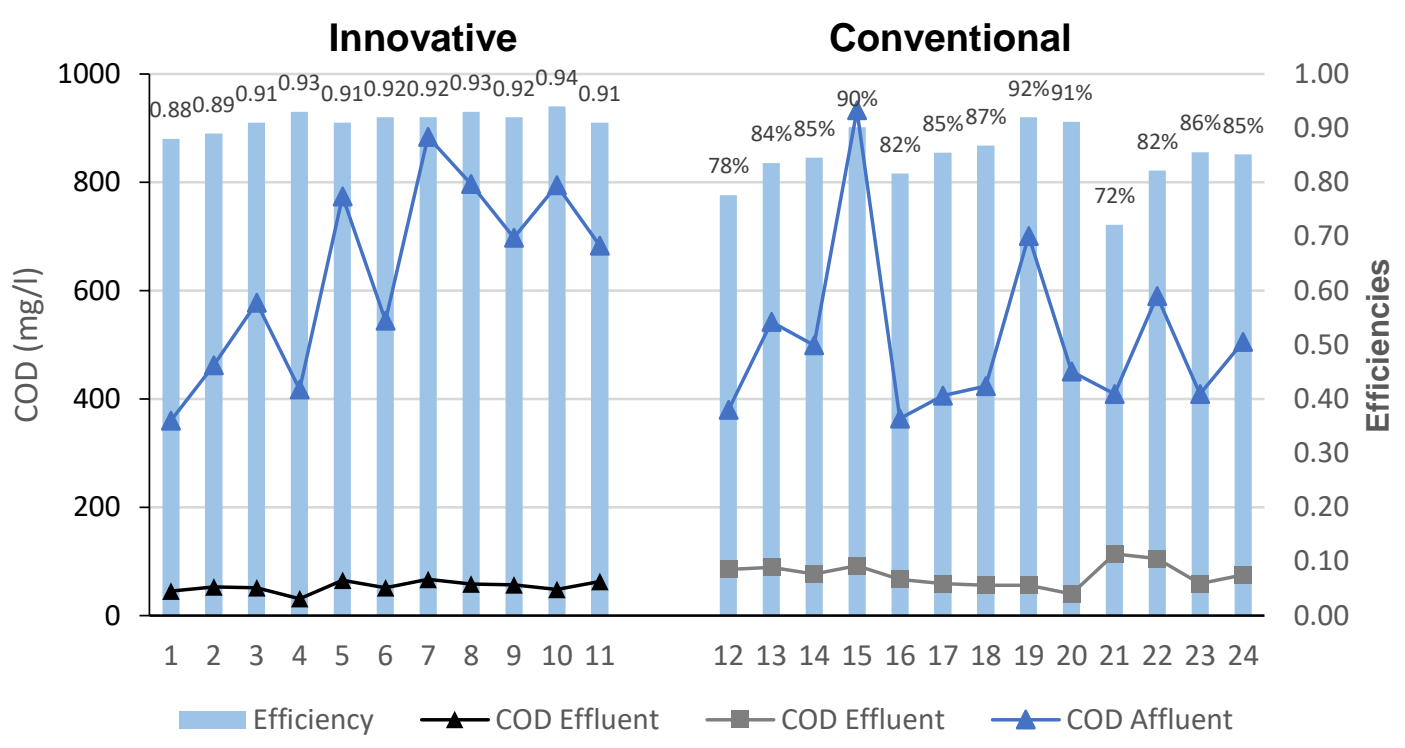

Figure 9. COD concentration in effluent and effluent in a Real-scale wetland.

On the other hand we have experiences of high efficiency of elimination of COD. [27] it studied the percentage of removal of the organic load of wastewater from a residential building that were treated with artificial wetlands, the sampling carried out during 25 days in the low season, the initial concentration was $164 \mathrm{mg} / \mathrm{L}$, and after passing through the system, it was $7 \mathrm{mg} / \mathrm{L}$, which means a 96\% removal. For the rainy season, the initial concentration in the residual water was $306 \mathrm{mg} / \mathrm{L}$ and at the exit of the system, $30 \mathrm{mg} / \mathrm{L}$, achieving a $90 \%$ removal.

[28] Evaluated 18 artificial subsurface flow wetlands planting Stipa ichu. Six of the wetlands were assembled without plants and twelve of them with plants, for the construction they used rectangular plastic containers with measures of $13 \mathrm{~cm}$ in height, $33 \mathrm{~cm}$ in length and $26 \mathrm{~cm}$ in width, and with a hole in the lower part that it collected the effluent, the COD removal efficiency of domestic wastewater was 92.43\% for wetlands without plants and 95.5\% for wetlands with plants. [29] Evaluated two wetlands with soil biotechnology plants (SBT). Plant I was controlled for a period of 12 months and an average COD of $266 \mathrm{mg} / \mathrm{L}$ was observed in the influent, while the value of the effluent was reduced to $32 \mathrm{mg} / \mathrm{L}$.

The COD elimination efficiencies of the mentioned experiences are similar to those of the real wetlands that have COD elimination efficiencies of $85 \%$ with conventional device and $92 \%$ with innovative device, with the application of the innovative patented device, the efficiencies could be improved, the Residential Building and the wetland with Stipa ichu approach the $100 \%$, wetlands with 
soil biotechnology plants from de 87 a $95 \%$; therefore, there is a feasibility to improve the efficiency of COD removal of these systems, which can be achieved by incorporating the innovative patented device.

That is why we have worked on a device that ensures reaching the efficiency values of the high elimination range, since the last experiences is all very close or over the $90 \%$, thus the differential shown in quality treatment of constructed wetland with the innovative device indicates that with this improvements, tend to achieve in elimination efficiency of COD terms, the highest values.

The following experiences show the application of constructed wetlands to wastewater of different nature to sewage, such as composting leachate, landfill leachate and wastewater from the pharmaceutical industry, which are more difficult to biodegrade than a domestic wastewater and achieving reasonable elimination results on the order of $74.5 \%$ of $\mathrm{BOD}$ and $53.7 \%$ of COD, for its application in composting leachates. In Isfahan, organic matter was removed from the leachate produced in the composting facility. The study was carried out in two horizontal flow wetlands with the dimensions of $1.5 \mathrm{~m} \times 0.5 \mathrm{~m} \times 0.5 \mathrm{~m}$. One of them was planted with Vetiveria zizanioides and the other wetland remained as control, without planting. They were operated with a leachate flow rate of $24 \mathrm{~L} / \mathrm{d}$ for more than five months. The control wetland eliminated $21.8 \%$ of BOD5 and $26.2 \%$ of COD and the planted wetland eliminated $74.5 \%$ of BOD5 and $53.7 \%$ of COD [30]. The removal efficiencies of two horizontal subsurface flow wetlands were also investigated by [31]. One of downflow (F1) and the other of upflow (F2), both filled with the hybrid substrate zeolite-slag for the treatment of leachates in rural landfills. The results showed that constructed wetlands were able to eliminate the following range of COD, 20.5-48.2\% (F1) and 18.6-61.2\% (F2). [32] They applied an artificial subsurface flow wetland for the treatment of wastewater from a cosmetic and pharmaceutical industry, using a system of rooted emergent macrophytes (Cyperus papyrus) for the removal of organic loads, the initial concentration of $92 \mathrm{mg} / \mathrm{L}$ of BOD5,20 is reduced to a concentration of $20 \mathrm{mg} / \mathrm{L}$. The wetland showed a high efficiency in the removal of organic load of 79\% of BOD5,20.

The extension of the application of wetlands to different kinds of wastewater, reinforces the need to improve the efficiency of COD elimination and therefore use of the patent innovative device, in order to guarantee treatment efficiencies of $60 \%$ for all types of wastewater.

\subsection{Yields of the wetland with both devices.}

Figure 10 shows the yields of the removal of COD in the horizontal subsurface flow wetland during the start-up period, with the innovative and conventional device.

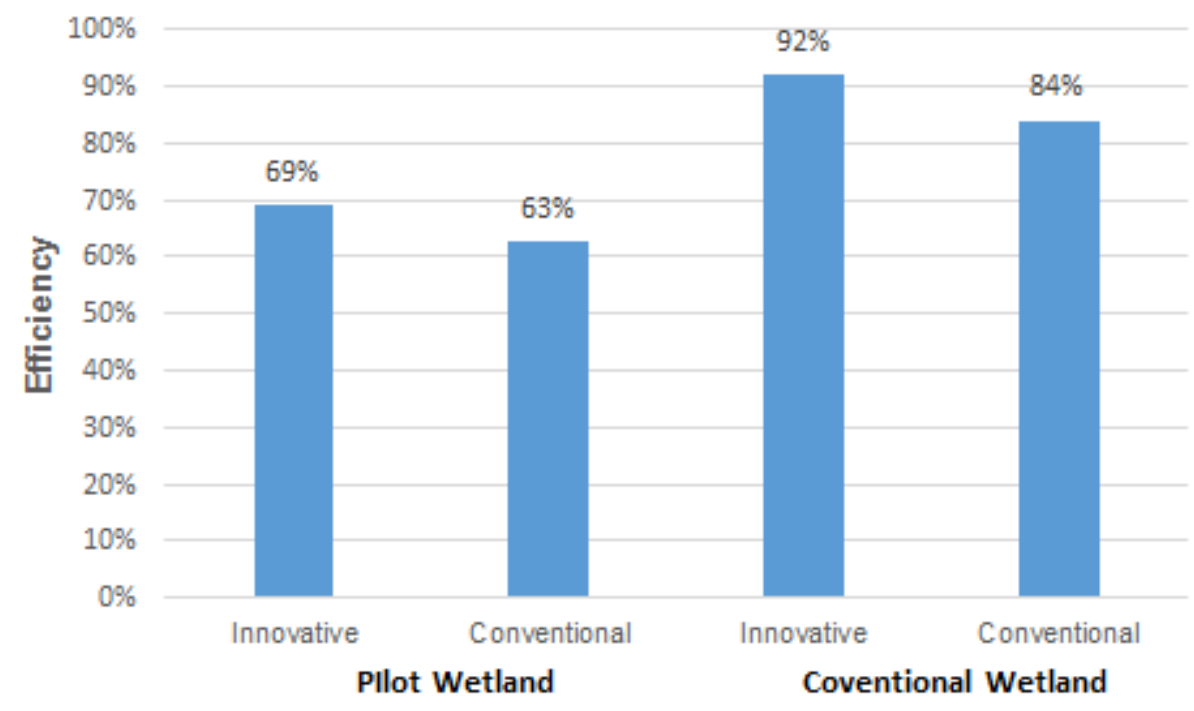

Figure 10. Average efficiencies of both devices in the removal of COD.

The figure 10 show that in both cases, real and pilot wetland, when the innovative device is used, efficiencies of $\mathrm{COD}$ with better performance are obtained, exceeding the conventional device performance by $6 \%$ and $8 \%$ respectively. 
The yields with the innovative device, allow obtaining better quality effluents with shorter residence times, therefore it is possible to reduce the extension of a wetland for the same treatment horizon, which is based on the efficiency of the innovative device of a $92 \%$, greater than $84 \%$ of the conventional.

The lower efficiency of the conventional device is attributed to the uniqueness and location, which causes the occurrence of preferential flows, leaving a volume with very little water movement, generating a decrease in both the height and effective volume of the wetland.

On the other hand, with the innovative device, having 4 equidistant catchment outlet pipes, it tends to generate a uniform flow that integrally occupies the cross-sectional area, using an effective height closer to the design height of the wetland.

When comparing the efficiencies of COD elimination, the effect of the innovative device is verified, which increases the elimination of COD.

On the other hand, the difference between the actual wetland and the pilot wetland is also observed, which is explained by the hydraulic residence times used for each experience, in the real wetland it is 2.8 days and the efficiency range of COD elimination it is between $84-92 \%$ and in the pilot wetland 1.2 days, the COD elimination efficiency range is between $63-69 \%$.

\section{Student's t-test analysis}

A Student's test analysis was made to compare the efficiency results between conventional and innovative device and verify if there are significant differences between them, both for pilot and real wetland.

We worked based on an alpha of 0.05 and under the following hypothesis:

$\mathrm{H}_{0}=0$

It indicates that there are no significant differences between the results of the COD removal efficiencies of the effluent from the wetland innovative with the wetland conventional.

$\mathrm{H}_{1} \neq 0$

It indicates that there are significant differences between the results of the COD removal efficiencies of the effluent from the wetland innovative with the wetland conventional both for pilot and real wetland.

By using Microsoft Excel, the t-Students analyses of the efficiency results are shown in Table 3.

Table 3. T-Students analysis results.

\begin{tabular}{|l|r|r|r|r|}
\hline \multicolumn{4}{|c|}{ T-Test for mean of two paired samples } \\
\hline \multirow{2}{*}{ Parameters } & \multicolumn{2}{c|}{ Pilot-scale Wetland } & \multicolumn{2}{c|}{ Real-scale Wetland } \\
\cline { 2 - 5 } & Innovative & Conventional & Innovative & Conventional \\
\hline Mean & 0.69 & 0.63 & 0.92 & 0.84 \\
\hline Variance & 0.0026 & 0.0019 & 0.00028 & 0.0035 \\
\hline Observations & 12 & 12 & 12 & 12 \\
\hline
\end{tabular}

For the case of the pilot-scale wetland, as the absolute value of the statistic $t(3.87)$ is higher than the critical value of $t$ two-tailed (2.20) and $P$ is smaller than 0.025 , the null hypothesis is rejected and approves $\mathrm{H}_{1}$, that is, there are significant differences between the results of the COD removal efficiencies of the effluent from the wetland innovative with the wetland conventional.

Furthermore, for the real-scale wetland, as the absolute value of the statistic $t(4.43)$ is higher than the critical value of $t$ two-tailed(2.20) and $P$ is smaller than 0.025 , the null hypothesis is rejected and approves $\mathrm{H}_{1}$, that is, there are significant differences between the COD results for the effluent from the wetland innovative with the wetland conventional.

\section{Conclusions}

It is observed that the wetland with the innovative device presents higher yields than those obtained with the conventional device. By obtaining higher yields with the innovative device, it allows achieving effluents of better quality, which is verified in that the performance of the innovative device has a COD 
removal efficiency of $92 \%$ being superior to the conventional device of $84 \%$, for the case of the full-scale wetland.

The innovative device has a COD removal efficiency of $69 \%$ being superior to the conventional device of $63 \%$, for the case of the pilot-scale wetland.

The t-Student statistical analysis to the results obtained from the pilot and real-scale wetlands, approved the hypothesis H1, that is, there are significant differences between the COD removal efficiencies from the innovative device with respect at the conventional device.

The innovative device achieves an efficiency of $10 \%$ over the conventional device in both the pilot and real wetland.

\section{References}

1. Rodríguez-Monroy J. y Durán de Bazúa C. “Remoción de nitrógeno en un sistema de tratamiento de aguas residuales usando humedales artificiales de flujo vertical a escala de banco". Tecnol. Ciencia 2006, 21st ed, pp. 25-33.

2. Ramalho, R.S. “Tratamiento de Aguas Residuales”, 1st ed.; Editorial Reverte S.A., México, 2002.

3. Saeed, T.; Sun, G. A review on nitrogen and organics removal mechanisms in subsurface flow constructed wetlands: Dependency on environmental parameters, operating conditions and supporting media. J. Environ. Manag. 2012, Vol 112, pp 429-448.

4. Seoánez Calvo, M. “Tratado de gestión del medio ambiente urbano: Colección Ingeniería del Medio Ambiente”. Editorial Mundi-Prensa Libros, 2001. ISBN 9788471149596.395.

5. Lamchaturapatr J., Yi S.W. y Rhee J.S. Nutrient removals by 21 aquatic plants for vertical free surface-flow (VFS) constructed wetland. Ecol. Eng, 2007. Vol 29, pp 287-293.

6. Persson, J. Somes, N. L. G. Wong, T. H. F. “Hydraulics Efficiency of constructed Wetlands and ponds”.Wat.Sci. Tech, 1999. Vol. 40, No 3, pp 291-300, 1999.

7. Lara, J. “Depuración de Aguas Residuales Municipales con Humedales Artificiales". Master degree, Mg. Ing. Gest. Amb. Universidad Politécnica, Instituto Catalán de Tecnología. Barcelona, España, 1999.

8. García, J. Morató. J y Bayona, J.M. “Depuración con sistemas naturales: humedales construidos”. Sección de Ingeniería Sanitaria y Ambiental, Departamento de Ingeniería, Marítima y Ambiental, Universidad Politécnica de Catalunya, c/ Jordi Girona 1-3, Módulo D-1, 08034. Barcelona, 2003.

9. Ardila A.N. "Remoción fotocatalítica de DQO, DBO5 y COT de efluentes de la industria farmacéutica. Revista Politécnica, 2012. Vol 15, pp. 9-17.

10. Vymazal J. Horizontal sub-surface flow and hybrid constructed wetlands systems for wastewater treatment. Ecol. Eng, 2005. Vol 25, pp 478-490.

11. Brix, H. Macrophyte-mediated oxygen transfer in wetlands: transport mechanisms and rates. Constructed wetlands for water quality improvement, 1993. pp. 391-398

12. Lahora A. Depuración de aguas residuales mediante humedales artificiales: La EDAR de los Gallardos (Almeria). Gestión de aguas del levante almeriense, Almeria, España, 2001.

13. Garcia, J., \& Corzo, A. Guía práctica de diseño, construcción, y explotación de sistemas de humedales de flujo subsuperficial. Catalunya, 2008.

14. Pérez, M. Análisis del establecimiento de Typha y Phragmites en humedales artificiales de flujo superficial y subsuperficial". Title Project Agricultural Civil Engineering, Universidad de Concepción, 2010.

15. E.P.A. "Constructed wetlands treatment of municipal wastewaters". United States Environmental Protection Agency EPA/625/R-99/010, 2000.

16. Delgadillo, O. Camacho, A. Pérez, L. y Andrade, M. "Depuración de aguas residuales por medio de humedales artificiales". Centro Andino para la gestión y uso del agua. Bolivia, 2010.

17. Steiner G.R., Watson J.T. and Choate K.D. General design, construction, and. operation guidelines for small constructed wetlands wastewater treatment systems. In: Constructed Wetlands for Water Quality Improvement. G. A. Moshiri Ed., Lewis, Boca. Raton, 1993, pp. 203-217.

18. Kadlec, R.H \& Knight, R.L. “Treatment wetlands". CRC Press, 1996, 893 pp, Florida.

19. Reed S.C, Crites R.W, Middlebrooks, E.J, Natural systems for waste management and treatment, 2nd Ed, McGraw-Hill, 1995.

20. W.E.F. "Design of Municipal Wastewater Treatment Plants". Manual of Practice No.8 and ASCE Manual and Report on Engineering Practice No.76, Volume II, Book Press, Inc. Brattleboro. Vermont, 1992. 
21. Metcalf, Eddy, I. Wastewater engineering, treatment and reuse. 4th ed, 2003.

22. National Institute of Industrial Property, INAPI, Chile, https://www.inapi.cl/

23. Henze, M.; Harremoes, P.; Jansen, J.C.; Arvin, E. Wastewater Treatment, Biological and Chemical Processes; Springer: Berlin, Germany, 1995.

24. Salazar, R. P., Chinchilla, C. A., Marín, J. S., \& Pérez, J. A. (2013). Evaluación del funcionamiento de un sistema alternativo de humedales artificiales para el tratamiento de aguas residuales. Uniciencia, 2013. Vol 27, No 1, pp. 332-340.

25. Marecos do Monte, H.; Albuquerque, A. 'Analysis of constructed wetland performance for irrigation reuse'. Water Sci. Technol., 2010. Vol 61, No 7, pp 1.699-1.705.

26. Fountoulakis, M. S., Daskalakis, G., Papadaki, A., Kalogerakis, N., \& Manios, T. Use of halophytes in pilot-scale horizontal flow constructed wetland treating domestic wastewater. Environmental Science and Pollution Research, 2017. Vol 24, No 20, pp 1-8.

27. Romero M, Colín A, Sánchez E, Ortiz L. Wastewater treatment by an artificial wetlands pilot system: evaluation of the organic charge removal. Rev. Int. Contam. Ambient, 2009. Vol 25, No 3, pp 157-167.

28. Hernández, D., Ramos, N., Castillo, J. \& Orduña, J. “Efficiency assessment of sub-surface flow wetlands using Stipa ichu for treatment of domestic wastewater. Ingenium, 2015. Vol 9 No 25, pp 47-59.

29. Kamble, S. J., Chakravarthy, Y., Singh, A., Chubilleau, C., Starkl, M., \& Bawa, I. A soil biotechnology system for wastewater treatment: technical, hygiene, environmental LCA and economic aspects. Environmental Science and Pollution Research, 2017. Vol 24, No 15, pp 1-20.

30. Bakhshoodeh, R., Alavi, N., Majlesi, M., \& Paydary, P. Compost leachate treatment by a pilot-scale subsurface horizontal flow constructed wetland. Ecological Engineering, 2017. Vol 105, pp 7-14.

31. He, H., Duan, Z., Wang, Z., \& Yue, B. The removal efficiency of constructed wetlands filled with the zeolite-slag hybrid substrate for the rural landfill leachate treatment. Environmental Science and Pollution Research, 2017. Vol 24, No 21, pp 1-9.

32. Salazar, R. P., Chinchilla, C. A., Marín, J. S., \& Pérez, J. A. (2013). Evaluación del funcionamiento de un sistema alternativo de humedales artificiales para el tratamiento de aguas residuales. Uniciencia, 2013. Vol 27, No 1, pp. 332-340. 